\title{
Morphofunctional Features in Angle Second Class Malocclusion on Dental Gypsum Models
}

\author{
CRISTIAN ROMANEC ${ }^{1}$, SORANA ROSU2 ${ }^{2}$, GEORGIANA MACOVEI ${ }^{3 *}$, MONICA MIHAELA SCUTARIU4*, BOGDAN DRAGOMIR ${ }^{1}$, \\ NICOLAE DANIEL OLTEANU 5 \\ ${ }^{1}$ Grigore T.Popa University of Medicine and Farmacy lasi, Department of Orthodontics, 16 Universitatii Str., 700115, Iasi, Romania \\ ${ }^{2}$ Grigore T.Popa University of Medicine and Farmacy lasi, Dental Medical Faculty, Discipline of community stomatology, 16 \\ Universitatii Str., 700115, Iasi, Romania \\ ${ }^{3}$ Grigore T.Popa University of Medicine and Farmacy lasi, Dental Medical Faculty, Diagnosis and Gerontostomatology, 16 Universitatii \\ Str., 700115, lasi, Romania \\ ${ }^{4}$ Grigore T. Popa University of Medicine and Pharmacy lasi, Dental Medical Faculty, Department Implantology, Removable \\ Restorations, Technology, Oro-Dental-Diagnosis and Gerontostomatology, 16 Universitatii Str., 700115, lasi, Romania \\ ${ }^{5}$ Dental-facial Orthodontics Orthopedics Clinic, Grigore T.Popa University of Medicine and Farmacy lasi
}

\begin{abstract}
The large diversity of clinical forms in Angle second class malocclusion explains the interest of researchers and clinicians in identifying changes in the dental arch in subdivisions II/1 and II/2. The purpose of the study is to identify the characteristics of the dental alveolar arch in order to determine the differences between class II/I and II/2 malocclusions. The study was conducted on dental gypsum models of 62 orthodontic untreated patients diagnosed with class II/1 Angle malocclusion, respectively class II/2. The results obtained by us reveals a statistically significant differentiation in the dental arcade, a narrowed maxillary arch at the molar level and elongated at premolar and molar level, in subdivision II/I. Our data are consistent with the results of literature. The knowledge of dental arch features serves to develop a correct and complete diagnosis and also to reach the therapeutic goals and to evaluate post-treatment response in short, medium and long term.
\end{abstract}

Keywords: dental arcade, malloclusion class II Angle, gypsum model

The dental anomaly has now become a public health problem due to its special features: wide spread in the population, with increasing general trend, aesthetic disturbances that may lead to difficulties in social integration of individuals, a complex etiopathogeny, disturbances in the general state of the organism [1-4[.

To establish a proper treatment it is required, first of all, to know the degree of spreading of the disease, the quantitative dimension of the phenomenon, but also the qualitative aspect expressed in the gravity index of the malocclusion.

The need for treatment is correlated with the development of the dentition. In Finland it is found that at the age of $7.23 \%$ of children have a malocclusion requiring immediate treatment, and $34 \%$ require repeated controls to observe the evolution of anomalies [5]. In Iceland, there is a prevalence of dentomaxillary anomalies of $11 \%$ in temporary dentition and $52 \%$ in permanent dentition [6].

Establishing an orthodontic diagnosis and treatment strategy involves knowing the characteristics of a dentomaxillary anomaly and also the identifying and quantifying changes in the dental and muscular skeleton [7-10]. The dental arch is defined by: size and shape. The interest in knowing this sector of the stomatognate system is determined by: the relations established between the dental arcade and the cranio-facial structures, the fact that the dental arcade often reacts, compensating for the disequilibrium at the skeletal level, and, importantly, that the dental intra-arch harmony has consequences on dental occlusion [11-15].

Researchers focused on the study of the relationship between the cranio-facial structures and the size of the dental arch in the subjects with malocclusions [16-18], finding that the maxillary dental arcade in class II/1 malocclusion is narrower in the dolicocephalus and wider at brahicephalus, while the size and shape of the mandible arch is similar to all three facial types (mesocephalic, brahicephalic, dolicocephalic). Other authors followed the characteristics of the dental arch by comparison between class II/I and class II/2 malocclusion, in subjects who did not perform orthodontic treatments [19-21].

While some researchers (19) find intercanines distances in the maxillar and mandible higher than in the class $1 \mathrm{I} / 2$ witness group and lower in class II/1, other researchers $[20,21]$ find in their studies a lesser intercanine distance compared to the average. Other researches refer to the characteristics of the dental arch in class II malocclusion as compared to the dental arch of children without abnormalities, revealing almost insignificant differences [22]. In contrast, Staley [23] finds larger intermolar and canine distances in children normally developed than those with Angle second class.

The large diversity of clinical forms in Angle class II malocclusion explains the interest of researchers and clinicians in identifying changes in the dental arch in subdivisions II/ 1 and II / 2 as well as the differences that may exist between them.

The purpose of the study is to identify the characteristics of the dento-alveolar arch in order to determine the differences between class II/I, II/2 malocclusions.

\section{Experimental part \\ Materials and methods}

The study was conducted on gypsum dento-alveolar models of 62 orthodontic untreated patients diagnosed with class II/1 Angle malocclusion, respectively class II/2 Angle, 40 girls (64.5\%) and 22 boys (35.5\%). 


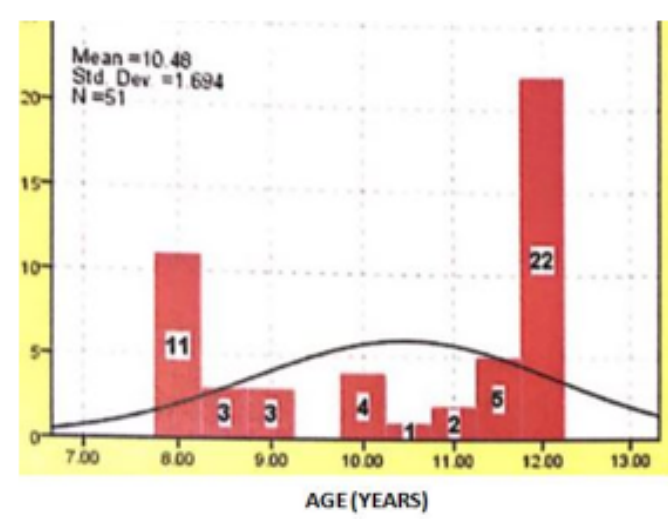

Regarding the frequency, according to the two subdivisions of the 2nd Angle class, the distribution was: 35 subjects with class II / 1 Angle (56.5\%) and 27 subjects with class II / 2 Angle, (43.5\%) with an average age of 10.76 class II / 1 and 10.167 class II/2 (fig. 1).

The dental-alveolar arcades were made by the same doctor, and the molding and processing of the dental model by the same dental technician.

The measurements were made by two independent examiners, the differences being identified by a third examiner who also determined the average error.

The ideal values for the width and length parameters of the dental arch were calculated and the differences between measured and calculated values were made.

The database was computerized. Statistical processing was done using SPSS 16.0 programm (Statistical Package for Social Sciences).

We used descriptive statistical analysis methods for presenting the two clinical forms, including analysis of the central trend of distribution and variant or dispersion indicators.

In relation to the descriptive statistical analysis of the obtained results, we have previously verified the nature of

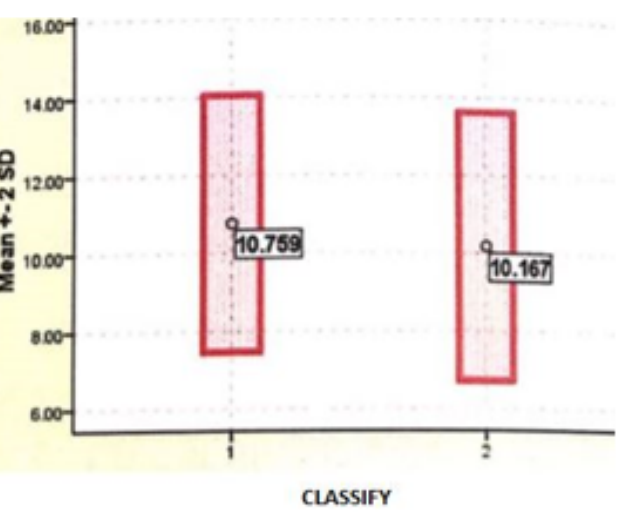

Fig. 1

the distribution of the values of the tested parameters. If the values of the tested parameters followed the normal law, we used the ttest to analyze the differences between the two subdivisions, and when the measured parameter values did not follow the normal law, we used the nonparametric Mann-Whitney test.

\section{Results and discussions}

Characteristics dental alveolar arch

1. a) the width of the maxillary arch at the premolar level - shows an global average of 34.5 with a standard deviation of 2.5429; in the class II/1 subdivision the average value was 34.1034 and 35.1765 in the II/2 Angle subdivision, with a standard deviation of 2.7947 and 1.93602 (fig.2). The difference from the required value (fig.3) showed an average over the whole group of -4.5183 (fig.4), with a standard deviation of 3.4998; in class II/I, the average difference was -5.1886 and -3.3747 in class II/2 with standard deviations of 3.5269 and 3.2369 (fig.4).

In conclusion, the maxillary arcade is narrowed at the premolar level more in II/I than in II/2, but insignificantly statistically.
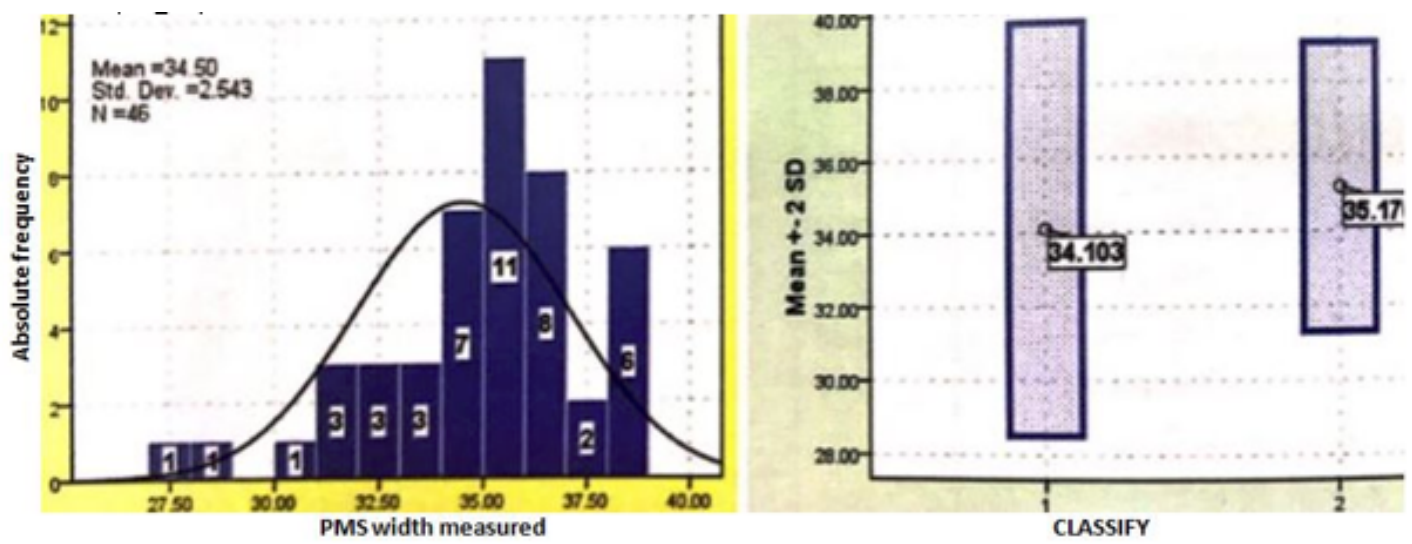

Fig. 2
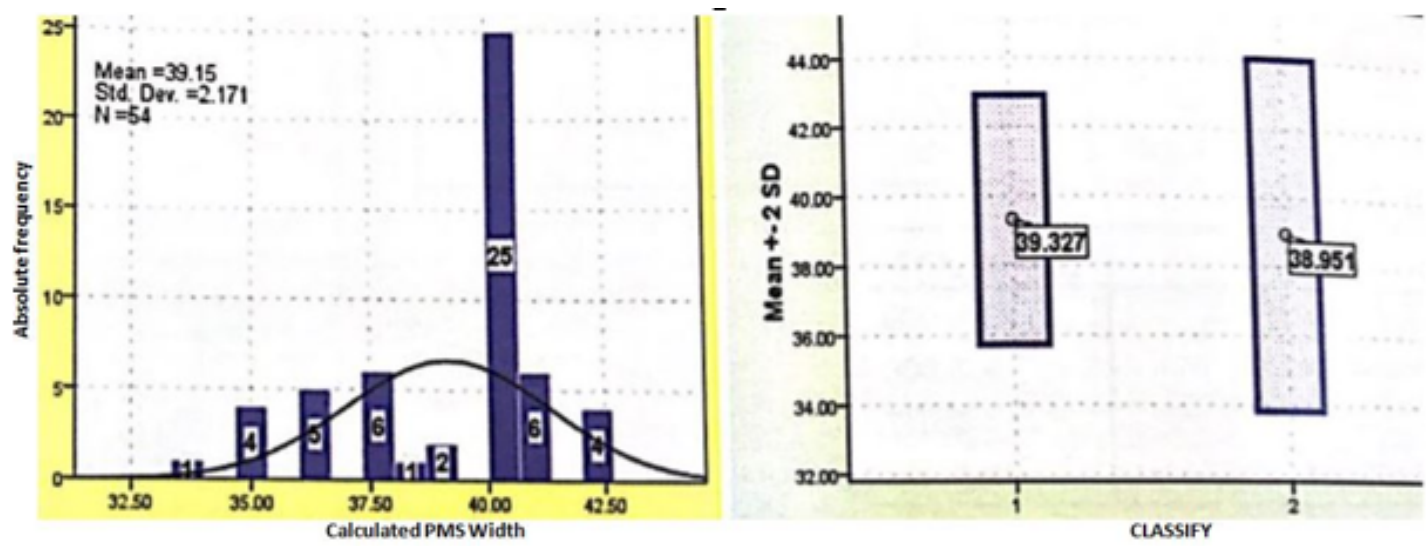

Fig. 3 

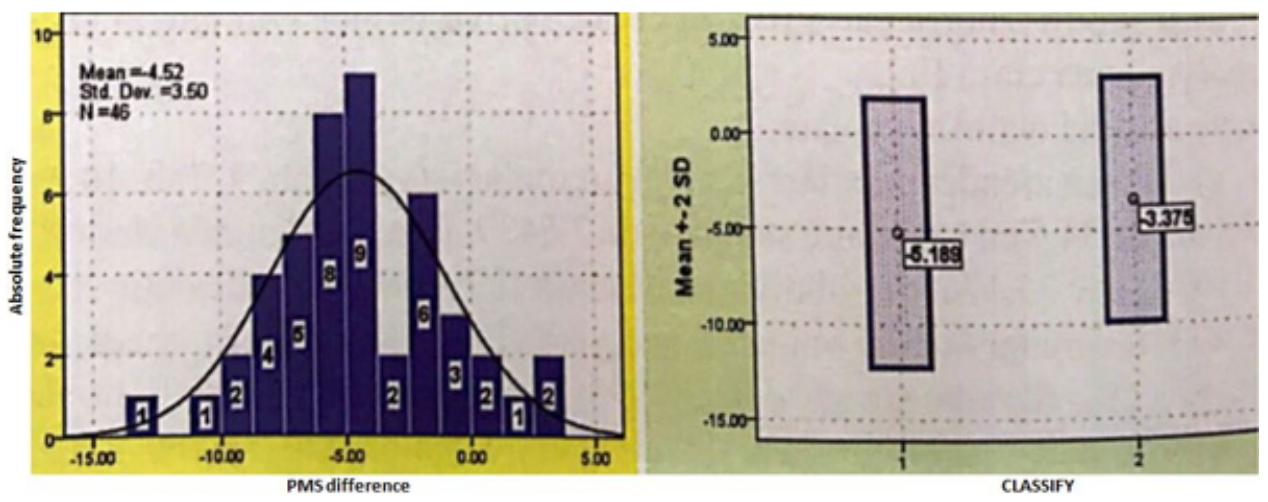

Fig. 4
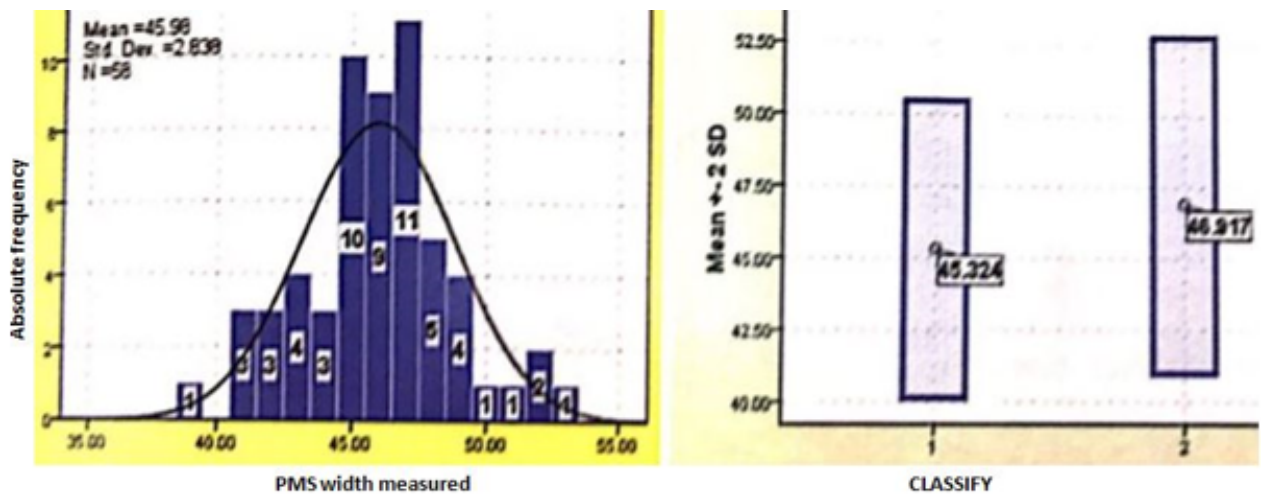

Fig. 5

The arcade width at the molar level

The global average of this parameter was $45.9828 \mathrm{~mm}$ (fig.5), with a standard deviation of 2.8376; in class II/1, it was $45.3235 \mathrm{~mm}$ and $46.9167 \mathrm{~mm}$ in class $\mathrm{II} / 2$, with a standard deviation of 2.5904 and 2.9623 (fig.5).

The difference from the value of dento-alveolar equilibrium (fig.6) is -2.6988 global, with a standard deviation of 3.9889 (fig.6); a value that ensures balance in subdivisions II/1 and II/2 is 48,66 and 48.397 respectively, resulting in a difference of -3.3 in the class II/1 and 1.8471 respectively in class $11 / 2$, with standard deviations of 3.9541 and 3.9763.
1. b). the length of the maxillary arch at the premolars level

The global average of the arcade length was $18.9674 \mathrm{~mm}$, with the standard deviation of 2.2494 (fig.7); in class II/I the average was 19.6552 and 17.7941 in class II/2, with standard deviations of 2.0402 and 2.1510 respectively (fig.7).

The difference that ensures the equilibrium of the arcade in the premolar area at the global level is 19.75, and the values that ensure the equilibrium in subdivisions $1 / / 1,11 / 2$ are 19.64 and 19.86, respectively.
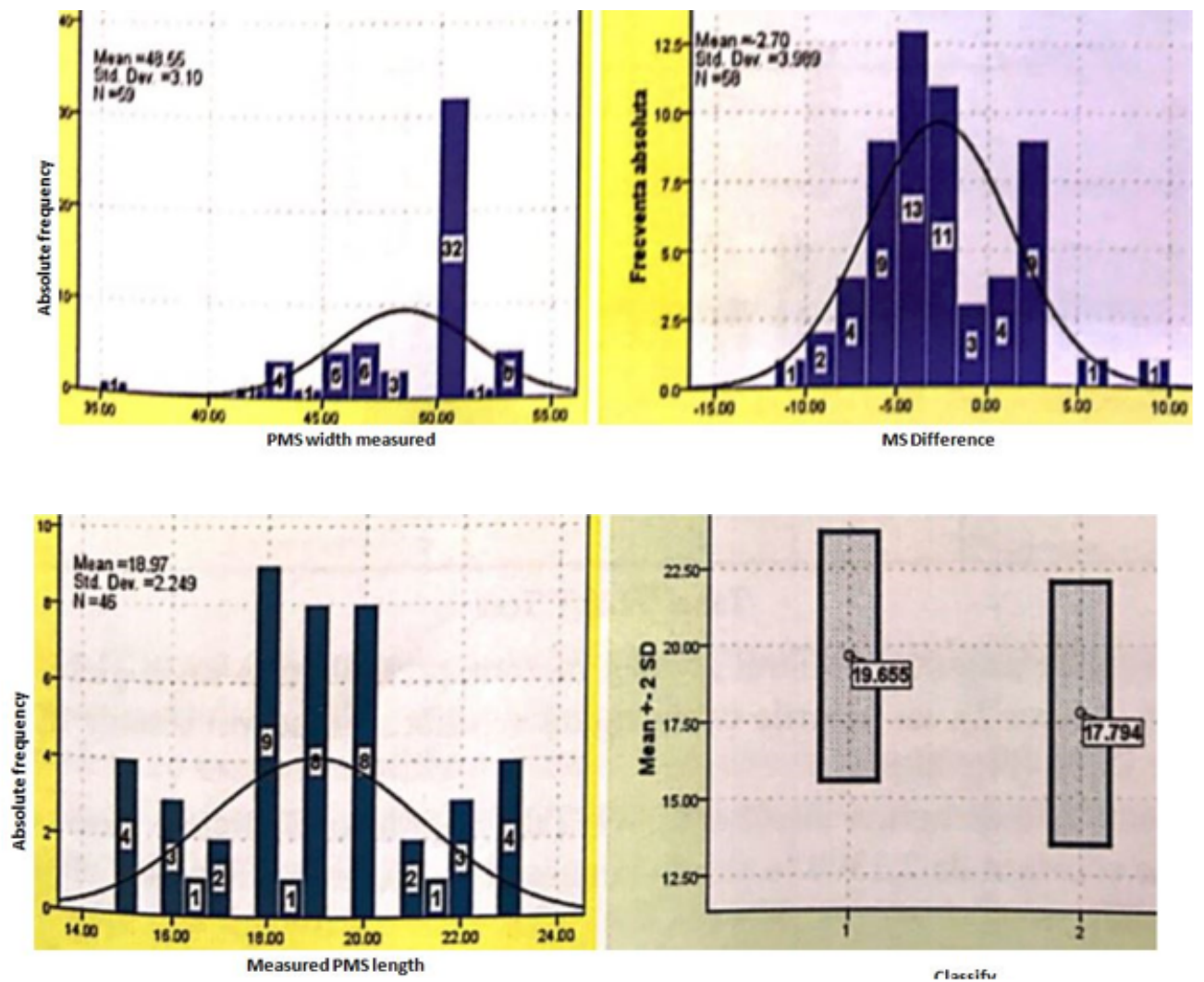

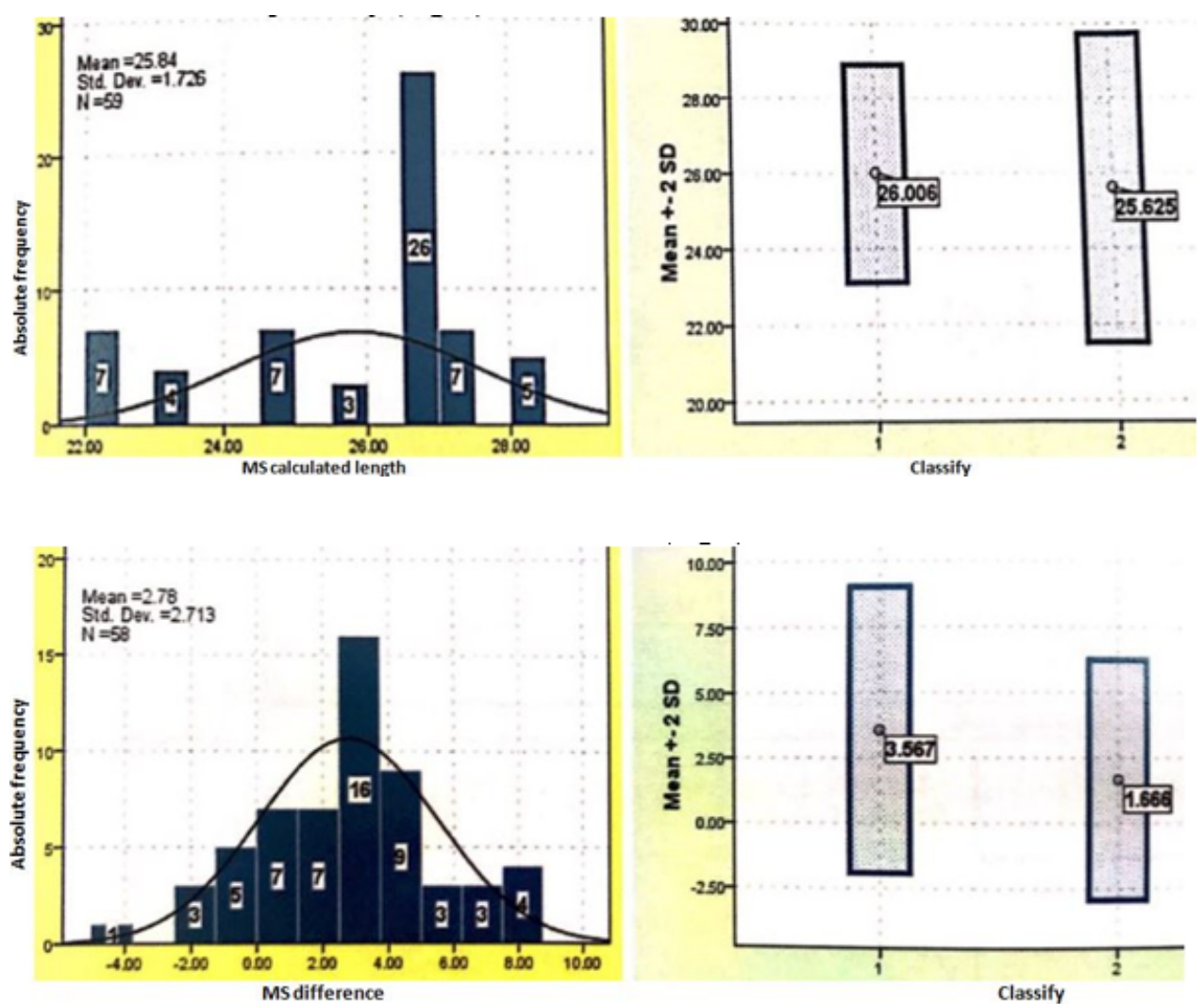

Fig.9

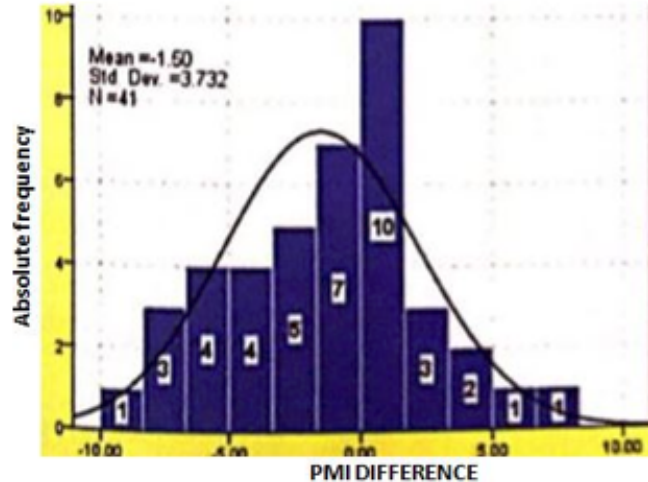

The difference from the ideal norm shows an global average of 0.7598 , with a standard deviation of 2.2390 in subdivision II/1, the difference was 0.0031 and -2.0506 in class II/2.

The length of the arcade at the molar level

The global average of the group at the level of the upper molar was 25.84, with a standard deviation of 1.76 . In subdivisions the average was 26.006 in $11 / 1$ and 25.625 in II/2, with standard deviations of 2.6777 and 1.6151 .

The difference that ensures the equilibrium of the maxillary arcade at the global level is 28.71 (fig. 8), and the values that ensures the equilibrium in subdivisions II/ I, II/2 are 29.74 and 27.25 , respectively (fig. 8).

The difference from the ideal norm is 2.7805 , with a standard deviation of 2.7134 . In subdivisions the average was 3.5671 and 1.663 in subdivision II/2, with standard deviations of 2.7399 and 2.2945 .

There are statistically significant differences between Class II/1 and Class II/2 Angles in the molar width ( $p=$ $0.034)$; the arcade is narrowed in class II/1.

There are statistically significant differences between subdivisions of class II/1 and class II/2 Angles in arcade length at both premolar $(p=0.005)$ and molar $(p=0.000)$ : in class II / I the arcade is longer.
2. a) The width of the dental arch at the premolar level The global average of the batch at the lower premolar level was 37.77, with a standard deviation of 3.3318 (fig.9). The average in subdivisions were 38.92 in II/1 and 35.9688 in II/2, with standard deviations of 2.8419 and 3.3189 (fig.9).

The difference that ensures the equilibrium of the mandibular arch at the global level in premolar area is 39.16, and the equilibrium values in subdivisions $1 / / 1,1 / 2$ are 39.475 and 38. 847, respectively.

In the class II/I subdivision was -0.955 , in class II/ 2 being -2.342 , with standard deviations of 1.6699 and 2.4871 .

The arcade width at the mandibular premolar level is statistically significant $p=0.004$, lower in class II/2.

The width at the molar level

The difference from the ideal value indicates an average of 1.9186, with a standard deviation of 4.4781. In class II/1 the average difference is -2.2562 and in Class II / 2 it is 1.4290 with standard deviations of 4.6772 and 4.2423 .

2. b) The length of the mandibular arch at the premolar level

The global average of the batch at the lower premolar level was 16.90, with a standard deviation of 1.655 (fig.10). In subdivisions the average was 17.12 in II / I and 16.562 in II/2, with standard deviations of 1.6411 and 1.6720 (fig.10). 
The difference that ensures the equilibrium of the maxillary arcade in the lower premolar area on a global level is 17.77, with a standard deviation of 1.477 , and the equilibrium values in subdivisions II /1, II/2 are 17.73 and 17.79 , respectively.

The difference from ideal values is -0.7751 on the global lot, (fig. 41). In the class II// the difference is -0.697 and 0.897 in II/2, with standard deviations of 1.7884 and 2.1888.

The differences are smaller between $I / 1$ and II/2, with a discreet shortening in II/2 at the premolar level.

\section{The length of the mandibular arch at the molar level}

The difference from the ideal value is 2.0841 on the whole lot, with a standard deviation of 2.6358. In subdivisions II/I the difference was 1.6172 and 2.6995 in subdivision II/2, with a standard deviation of 2.6559 and 2.5374 .

The depth of the palatine veil indicates an average of 8.1441 in the whole study group, with a standard deviation of 3.2043. In subdivision II/1, the average of palatine veil depth was 8.7941 and 7.2600 in II/2, with a standard deviation of 3.3555 and 2.8141 respectively.

From the point of view of the depth of the palatine veil, no significant statistic differences exist between Class II/ $1, \| / 2$.

\section{Results and discussions}

The results obtained by us reveals a statistically significant differentiation in the dental arcade, the group investigated by us reveals a narrowed maxillary arch at the molar level and elongated at premolar and molar level, in subdivision II/I. Our data are consistent with the results of literature [19-22]. At the same time it confirms McNamara's opinion, who believes that in class II/I malocclusion there is a transversal component, which will also influence the treatment algorithm [24].

From the therapeutical point of view, the conclusion regarding the narrowing of the maxillary arch in class II/1 agree with the relation of jaw expansion/disjunction, in order to harmonize the dental springs for obtaining an eugnate occlusion. As far as the mandible arch is concerned, itshows more stability compared to the maxilla, which is highlighted in the specialized literature [16].

There is a decrease in the width and, significantly, in the premolar length, as evidenced by Pancherz's studies [25]. The shortening of the mandibular arcade in the caninepremolar region is considered a consequence of the high degree of overcoat, which produces the inferior retroalveolodention, in class II/2 malocclusion [26].

Dento-maxillary anomaly can have a major impact on the population, due to the damages of the dento-alveolar apparatus, which reflects on the general health status of the population. On the other hand, it is necessary to know the index of addressability of the population towards the dental care services, in general, and towards the orthodontics and dental-facial orthopedics, in particular. Treatment complexity index and treatment priorities can be established taking into account important data, like: the identification of the clinical manifestations of the anomaly, the etiological factors and the treatment needs [27-29].

\section{Conclusions}

Changes in class II malocclusion demonstrate that alters both dental and alveolar level. The maxillary dental arch is narrowed and elongated in subdivision II/I. The mandibular dental arch is narrowed and shortened in the anterior section of the premolar region. The knowledge of dental arch features serves to develop a correct and complete diagnosis and also to reach the therapeutic goals and to evaluate post-treatment response in short, medium and long term

\section{References}

1.ROMANEC, C., PACURAR, M., DECUSARA, M., SCUTARIU, M.M," HINGANU, D., HINGANU, M.V., CIUPILAN, C., Rev. Chim. (Bucharest), 69, no.4, 2018, p. 1002.

2.HINGANU, D., STAN, C.I., TARANU, T., HINGANU, M.V. Rom J Morphol Embryol, 58, no.4, 2017, p.1327.

3.LUPASCU, F.G., AVRAM, I., AVRAM, L., CONSTANTIN, S.M., STAN, C.I., LUPUSORU, E.C., SAVA, A., PROFIRE, L., FARMACIA, 65, no. 4, p. 508.

4.FRANCU, L.L., HINGANU, D., HINGANU, M.V., Rom J Morphol Embryol, 54, no.3 Suppl., 2013, p. 757.

5.HEIKINHEIMO KAISA - Need of orthodontic treatment and prevalence of cranio-mandibular dysfunction in Finnish Children Turku - Finland, 1989;

6.MAGNUSSON, T.E., Community Dent Oral Epideiniol, 5, 1977, p. 292. 7.MARTHA, K., OGODESCU, A., ZETU, I., OGODESCU, E., GYERGYAY, R., PACURAR, M., Mat. Plast., 50, no.3, 2013, p. 208.

8.ROMANEC, C., DOROBAT, V., ZETU, I.N., REVISTA ROMANA DE BIOETICA, 11, no.3, 2013, p. 66.

9.SOLOMON, S.M., FILIOREANU, A.M., STELEA, C.G., GRIGORAS, S.I., SUFARU, I.G., MAFTEI, G.A., MARTU, S., SCUTARIU, M.M., POPA, C. Rev. Chim. (Bucharest), 69, no.2, 2018, p.507.

10.CIURCANU, O.E., STEFANESCU, O., SCUTARIU, M.M., STELEA, C.G. Rev. Chim. (Bucharest), 67, no.3, 2016, p.566.

11.HINGANU, D., SCUTARIU, M.M., HINGANU, M.V. ANNALS OF ANATOMY-ANATOMISCHER ANZEIGER, 218, 2018, p. 271. https:// doi.org/10.1016/j.aanat.2018.04.009.

12.MARTHA, K., OGODESCU, A., BICA, C., OGODESCU, E., ZETU, I., Rev. Chim. (Bucharest), 64, no.8, 2013, p. 875.

13.ROMANEC, C., DRAGOMIR, B., BICA, C., Rev Chim (Bucharest), 69, no.3, 2018, p. 693.

14.MESAROS, A.S., ROMANEC, C., MESAROS, M., MOLDOVAN, M., BALDEA, I., Mat. Plast., 54, no.4, 2017, p.620.

15.BARLEAN, L.M., AUNGURENCEI, A., AUNGURENCEI, O., SCUTARIU, M.M., BALCOS, C., MOISEI, M. Rev. Chim. (Bucharest), 66, no. 11, 2015, p. 1877.

16.KANASHIRO, L.K., VIGORITO, J.W.A., Orthodontia, 33, 2000, p.8. 17.BREZNIAK, N., ARAD, A., HELLER, M., DINTE A., WASSERSTEIN, A., Orthodontist, 72, no.3, 2002, p. 251.

18.MARTHA, K., OGODESCU, A., ZETU, I., OGODESCU, E., PACURAR, M., Rev. Chim. (Bucharest), 64, no.9, 2013, p. 982.

19.MOORREES, C.F.A., GRON, A.M., SEBRET, L.M.L., YEN, P.K.J ., FROHLICH, F.J., American J ournal of Ortbodontics, 55, 1969, p.600. 20.BUSCHANG, P.H., STROUD, J., AIEXANDER, R.G., Eur.J .Orthod, 16, 1994, p. 47.

21.WALLOW, T.M., PECK, S., Am. J. Orth. \& Dentofacial orth, 122, 2002, p. 608.

22.ISIK, F., DIDEM, N., KORKAMAZ, S., TULIN, A., Europ.J of Orthodontics, 28, 2006, p. 179.

23.STALEY, N.R., STUNTZ, W.R., PETERSON, L.C., Am. J. Orthod., 88, 1985, p.163.

24.Mc NAMARA JR.A.J., Maxillary transverse deficiency, Am.J ournal Orthod. And Dentofacial Ortop.2000, 117, 567-70;

25.PANCHERZ, H., Am J Orthod Dentofacial Orthop, 85, 1984, p. 125. 26.LAPATKI, B.G., MAGER, A.S., SCHULTE-MOENTING, J., JONAS, I.E., Journal of Dental Research, 81, 2002, p.323.

27.COSTACHE, I.I., UNGUREANU, M.C., ILIESCU, D., PETRIS, A., BOTNARIU, G.,. MEDICAL-SURGICAL JOURNAL-REVISTA MEDICOCHIRURGICALA, 119, no.1, 2015, p.18.

28.PETRIS, A., CIMPOESU, D., COSTACHE, I., ROTARIU, I., REVISTA ROMANA DE BIOETICA, 9, no,2, 2011, p.99.

29. HINGANU, D., HINGANU, M.V., MIHALCEANU, E., CALIN, A.M., PANGAL, A., COSTACHESCU, G., ROMILA, A., Rev Chim (Bucharest), 69, no. 2, 2018, p. 714.

$\overline{\text { Manuscript received: } 15.08 .2018}$ 